The expression of terminal deoxynucleotidyl transferase and paired box gene 5 in Merkel cell carcinomas and its relation to the presence of Merkel cell polyomavirus DNA

Johansson, Benjamin

2019-01

Johansson, B , Sahi , H , Koljonen, V \& Böhling , T 2019 , ' The expression of terminal deoxynucleotidyl transferase and paired box gene 5 in Merkel cell carcinomas and its relation to the presence of Merkel cell polyomavirus DNA ', Journal of Cutaneous Pathology , vol. 46 , no. 1 , pp. 26-32 . https://doi.org/10.1111/cup.13372

http://hdl.handle.net/10138/325693

https://doi.org/10.1111/cup.13372

unspecified

acceptedVersion

Downloaded from Helda, University of Helsinki institutional repository.

This is an electronic reprint of the original article.

This reprint may differ from the original in pagination and typographic detail.

Please cite the original version. 


\title{
The expression of terminal deoxynucleotidyl transferase and paired box gene 5 in Merkel cell carcinomas and its relation to the presence of Merkel cell polyomavirus DNA
}

\author{
Benjamin Johansson ${ }^{1}$ CM., Helka Sahi ${ }^{2}$ M.D., \\ Virve Koljonen ${ }^{3}$ M.D., Ph.D., Tom Böhling ${ }^{1}$ M.D., Ph.D.,
}

${ }^{1}$ Department of Pathology, Helsinki University and HUSLAB, Helsinki, Finland

${ }^{2}$ Department of Dermatology and Allergology, University of Helsinki and Helsinki University Hospital, Helsinki, Finland

${ }^{3}$ Department of Plastic Surgery, Helsinki University Hospital, Helsinki, Finland

Running title: TdT and PAX5 expression in MCC

Word count: 2142

Word count abstract: 198

Tables: 3

Figures: 1

Key words: Merkel cell carcinoma - Merkel cell polyoma virus - lymphocyte

Conflict of Interest Statement: Each author declares no financial conflicts of interest with regards to the data presented in this manuscript.

Correspondence to: Virve Koljonen, Department of Plastic Surgery, Töölö Hospital, P.O. Box 266, FI-00029 HUS, Finland. Email: virve.koljonen@ @us.fi, phone:

+ 35850427 1983, fax: + 358947187217 


\section{Abstract}

Background: Merkel cell carcinoma (MCC) tumor samples frequently express B-lymphoid lineage markers. However, the reasons for expression of specific B-lymphoid lineage markers are still unclear. We studied in a large pool of tissue microarray MCC samples, validate in a larger cohort the expression of TdT and Pax-5, which are two B-lymphoid lineage markers.

Methods: Immunoexpression and staining intensities of TdT and Pax-5 were statistically correlated with patient, tumor, Merkel cell polyoma virus (MCV), and disease-specific parameters.

Results: In a cohort of $117 \mathrm{MCC}$ patients and their corresponding tumor samples, TdT was expressed in 37 (31.6\%) samples and Pax-5 in 26 (22.2\%). Simultaneous immunostaining for TdT and PAX5 was observed in $13(11.1 \%)$ samples. A statistically significant relationship was observed between MCV virus copy number and positive TdT expression $(p=.0056)$. A similar significant relationship was also observed between positive TdT and tumor MCV virus positivity ( $p=.000495$ ).

Conclusions: We observed frequent TdT and PAX5 immunoexpression in MCC tumor samples. However, simultaneous immunoexpression of these markers was scarce. TdT expression was statistically significantly associated with MCV positivity. The absence of a statistically significant association between tumor parameters and disease progression markers undermines the systemic use of these markers in clinical practice.

\section{Word count: 198}




\section{Introduction}

Merkel cell carcinoma (MCC) is a neuroendocrine carcinoma of the skin. The cellular origins of this rare and highly aggressive skin cancer subtype are thus far unknown. On the basis of expression patterns, MCC tumor cells are considered to be most closely related to Merkel cells (MC), which are mechanoreceptive cells located in the basal layer of the epidermis. At the dermal-epidermal junction, the basal surfaces of the MCs are closely associated with the terminal bulbs of afferent myelinated nerve fibers. Together, the neuron and the Merkel cell are referred to as Merkel's corpuscle, which is a sensitive mechanoreceptor. In the vast majority of the MCCs (approximately 80\% of MCC tumors), the DNA genome of Merkel cell polyomavirus (MCV) is integrated in the tumor cell genome; this is considered as the causative agent for tumorigenesis in MCV infection $(1,2)$. We and others have previously demonstrated significant morphologic and clinicopathologic differences between MCV-positive and MCV-negative MCCs (2-6).

Terminal deoxynucleotidyl transferase (TdT) was one of the first DNA polymerases identified in mammals (7). DNA polymerases have a vital role in replication, repair, and recombination of nucleic acids. To guide each of these events, the polymerase extends a primer using a DNA or RNA template. However, TdT possesses the unusual ability to incorporate nucleotides without a template. TdT uses only single-stranded DNA as the nucleic acid substrate (7), thus synthesizing DNA without a templating strand. Furthermore, TdT has a potential role in the development of certain forms of leukemia. TdT is expressed in immature, pre-B, and pre-T lymphoid cells. TdT is also used as a marker for neoplasms of precursor B-cell and T-cell origin $(8,9)$. In addition to lymphoblastic neoplasms, TdT shows nuclear expression in other small round blue cell tumors such as medulloblastoma, Ewing sarcoma, pediatric rhabdomyosarcoma, and small cell lung carcinoma (10-12). Very recently, it was shown that TdT protein was expressed in cells of epithelial origin and specifically in sebaceous cells, both benign and malignant (13). PAX5 is one of nine mammalian Pax transcription factors. Thus far, PAX5 is the only Pax protein expressed within the hematopoietic system (14). PAX5 is essential for commitment of lymphoid progenitors to the B-lymphocyte lineage (14) and to $\operatorname{MCC}(15,16)$.

Expression of B-lymphoid lineage markers in MCC is frequent (Table 1), including TdT and PAX5. These markers are recurrent in MCC in both primary cutaneous tumors and metastatic lymph nodes 
(12,15-23). Nearly $90 \%$ of the tumors reported express PAX5 and 65\% express TdT (24). On the basis of the frequent expression of B-lymphoid lineage markers, zur Hausen et al. proposed that the cell of origin of MCC might in fact not be the post-mitotic MC, but rather either a pro/pre-B cell or a pre-B cell (21). Thus, the stage of early B-cell development in which a MCV infection occurs could determine the phenotype and B-cell expression profile of subsequent MCC (21).

We used immunohistochemistry to evaluate the frequency of PAX5 and TdT expression in a large pool of MCC samples. We also sought to determine whether there is an association between the immunoexpression of PAX5 or TdT (or both) and the presence of MCV DNA and patient and tumor characteristics. This current study validates in a larger cohort the previous smaller scale studies on the connection between MCC and B-lymphoid lineage markers. 


\section{Patients and methods}

The study protocol was approved by the Ethics Committee of Helsinki University Central Hospital. The Ministry of Health and Social Affairs granted permission to collect patient data and the National Authority for Medicolegal Affairs to collect tissue samples.

Patients, clinical data, and tissue samples Data on patients diagnosed with MCC in Finland from 1979 to 2004 was obtained from the Finnish Cancer Registry and Helsinki University Hospital files. Clinical details were extracted from hospital records. Formalin-fixed, paraffin-embedded tissue blocks were retrieved from the pathology archives. MCC diagnoses were confirmed in a blinded fashion from our earlier studies according to well-established criteria (25) by two researchers with special expertise in MCC pathology.

MCV detection from paraffinized tumor blocks was performed in our previous study and is described in detail elsewhere (26). In short, the presence of MCV DNA was analyzed from DNA extracted from representative deparaffinized tumor sections. Quantitation of MCV DNA was performed using real-time PCR. The relative DNA sequence copy number for each tissue sample was expressed as a ratio of MCV DNA to protein tyrosine phosphatase gamma receptor gene (PTPRG) DNA. The sample was considered positive whenever MCV DNA copy number per reference gene was greater than 0.1 (27). Tissue microarray (TMA) blocks with 342 tissue cores were used for immunohistochemistry.

Immunohistochemistry Five- $\mu \mathrm{m}$ sections were cut from TMA blocks to create three slides from each TMA block; one was stained with hematoxylin and eosin to create a reference slide (Figure 1) and one each was used for immunohistochemical staining of PAX5 and TdT.

Staining for both TdT and PAX5 was performed in a BenchMark XT (Roche Ventana, Tucson, Arizona USA). For TdT, the antibody used was NCL-L-TdT-339 (clone SEN28) (Novocastra Laboratories Ltd, Newcastle, UK) at 1:50 dilution with an incubation time of 32 minutes at room temperature. For PAX5, the antibody was 790-4420 (clone SP34) "Ready to use antibody" (Roche Ventana, Tucson, Arizona USA); the incubation time was 44 minutes at room temperature. The detection kits were OptiView DAB (Roche Ventana, Tucson, Arizona USA) and UltraView DAB with amplification kit (Roche Ventana, Tucson, Arizona USA). In both cases, counterstaining was performed with Mayer's Hematoxylin 
(Lillie's modification) (Agilent, Santa Clara, CA USA) (code S3309) and the slides were cover slipped with Sakura@ Tissue-Tek Film.

Immunostaining evaluation TMA spots were examined and evaluated for expression of PAX5 and TdT by light microscopy. A grading system was used for the expression of PAX5 and TdT in which the spots were classified as showing no expression, weak positive expression, or positive expression. The degree of immunohistochemical expression was determined by the highest degree of expression observed. The slides were evaluated separately by three researchers (BS, HS, and TB) in a blinded fashion.

Morphological appearance The TMAs were evaluated by their cytomorphology to three categories; classic, small cell variant and large cell/pleomorphic variant.

Statistical analysis Statistical analysis was performed with NCSS 2007 (NCSS Statistical Software, Kaysville, UT, USA) software and SPSS statistics 19.0 software (IBM Corporation, NY, USA). $P$-values less than 0.05 were considered significant. Immunoexpression of TdT and PAX5 was compared with gender, age, tumor location and sun exposure pattern, tumor laterality, disease progression, and hematologic malignancy by Chi-Square test. The statistical association between the presence of MCV DNA and quantitative PCR results and immunoexpression of TdT and PAX5 were also evaluated statistically against clinical variables, virus copy number, virus positivity by qPCR, and CM2B4 immunohistochemical expression of MCV by Mann-Whitney analysis and Kruskal-Wallis analysis. The cytomorphological features were analyzed statistically against TdT, PAX5 and MCV status by ChiSquare test and Kruskal-Wallis One-Way ANOVA. 


\section{Results}

\section{Overview of the patients}

Detailed patient clinical data is shown in Table 2. Our cohort included 117 MCC patients, of which mean age was 78 years at the time of MCC diagnosis. The majority of the patients were female $85(72 \%)$. Seven (6\%) patients were previously diagnosed with a hematologic B-cell malignancy and two (1.7\%) were kidney transplant recipients. The most common location for the primary tumors was the head and neck region 65 (55\%). Chronic non-shield site tumors represented 66 (56\%) of all tumors. Half of the tumors, 58 located on the left side of the body. MCV tumor status was available for 113 patients, with $74 \%$ of them being MCV-positive tumors. None of the MCC tumors is this study were composite or collision tumors.

\section{TdT and PAX5 expression in MCC}

Table 3 and clarifies the expression patterns of TdT and PAX\% stratified by MCV status. In Figure 1 demonstrations of expression patterns are shown.

For TdT, we recorded positive immunostaining in $37(31.6 \%)$ samples. We observed strong positivity in 14 samples and weak positivity in 23 samples. Of the 37 positive TdT samples, 34 (91.8\%) were also MCV positive. We observed a statistically significant association between virus copy number and positive TdT $(\mathrm{p}=0.0056)$ in Mann-Whitney analysis. In addition, Fisher's exact test revealed a statistically significant association between TdT immunoexpression and MCV virus positivity $(p=0.000495)$.

Altogether, $26(22.2 \%)$ samples showed positive immunohistochemistry for PAX5. Immunoexpression was strong in six samples and weak in 20 samples. Of the 26 PAX5 positive samples, 19 (73\%) were also MCV positive.

Simultaneous immunostaining for TdT and PAX5 was observed in 13 (11.1\%) samples. We observed the following three different staining patterns: weak TdT and weak PAX5 in eight samples, strong TdT and 
strong PAX5 in four samples, and strong TdT and weak PAX5 in one sample. Absent immunostaining for both TdT and PAX5 was observed in 66 (56\%) samples.

Twelve out of the 13 (92\%) simultaneous TdT and PAX5 expression samples were also MCV positive, although no statistically significant associations were observed due to the small number of samples.

We did not observe any statistically significant associations between TdT or PAX5 immunoexpression and demographics or disease progression - gender, age, tumor location and sun exposure pattern, tumor laterality, disease progression, and hematologic malignancy.

There were $9783 \%$ of the classic variant, 15 (13\%) small cell variant and five (4\%) large cell/pleomorphic variant cytomorphology in the TMAs. In the statistical analysis, there were no correlation between cytomorphology features and immunoexpression of TdT and PAX5 or MCV. 


\section{Discussion}

We studied the immunoexpression of two lymphoid lineage markers (TdT and PAX5) from a large collection, 117 samples, of MCC tumor material. In this study, we validated in a larger cohort the previous results of the connections between B-lymphoid markers and MCC. We observed that $31.6 \%$ of the 117 MCC samples were positive for TdT (clone SEN28) immunohistochemistry and 22.2\% were positive for PAX5 (clone SP34) immunohistochemistry. The results of this current study are quite different from those previously reported $(12,21)$.

Regarding PAX5, in the previous studies, overall PAX5 expression is detected in $89.5 \%$ of 143 MCC samples (24). All the samples tested by zur Hausen et al. and Murakami et al. in two separate studies were PAX5 positive $(21,22)$ and in the low end of expression, Mhawech-Fauceglia et al. reported $70 \%$ expression of PAX5 in 24/34 MCC samples (17). Thus our PAX5 positivity is judged low. To derive the reason for the disagreement we looked at the antibody clones used in those studies. Zur Hausen and Murakami used the same antibody clone - Dako; clone: DAK-Pax5 - -with parallel 100\% PAX5 expression rates $(21,22)$, further Dong et al. and Mhawech-Fauceglia et al. studies employed the same antibody clone - clone 24 , BD Biosciences $(16,17)$ with $93 \%$ and $70 \%$ positivity, respectively. Hence, at least part of the expression is -dependent on the primary antibody used. Obviously, we acknowledge the limitation of using TMA cores in this study, that may have influenced the results. On the other hand, PAX5 expression is typically uniform, with only very few cases showing focal expression (16). Considering the TdT expression, previous meta-analysis established 65\%,122/187, expression in MCC (24), ranging from $21 \%$ (28) to $76 \%$ (21). Our current expression rate of $32 \%$, falls nicely in this range.

Simultaneous expression of both markers in this present study, was scarce and observed only in $11.1 \%$ of the samples. Previously, all of the 21 MCC samples that zur Hausen et al. analyzed, showed coexpression of PAX5 and TdT in $72.8 \%$ of the samples. These seemingly contradictory findings suggest the possibility that the high rates of PAX5 and TdT expression might be partly explained by chance, given the relatively low number of MCCs studied or antibody clone used. Of note, we observed that PAX5 and TdT expression evaluation in MCC was occasionally confounded by the strong expression of these proteins by tumor-infiltrating leukocytes. Expression of TdT, PAX5 or their simultaneous expression did not correlate statistically significantly with patient or disease parameters, - gender, age, 
tumor location and sun exposure pattern, tumor laterality, disease progression, or hematologic malignancy.

Corroborating the zur Hausen theory, we observed a strong statistically significant association between virus copy number and TdT expression $(P=0.0056)$ and between MCV positivity and TdT expression $(P=0.000495)$. Previously, Bhatia et al. found a similar relationship between TdT immunohistochemical staining and MCV viral abundance $(P=0.003)$ (28). In about $80 \%$ of MCC tumors $(2)$, oncogenesis is initiated by MCV infection in the cell of origin (1). For MCV to initiate MCC tumorigenesis a series of specific mutations are required (29); without these crucial mutations MCV is just a passenger virus. In this study, the threshold of viral copy numbers determining MCV positivity was set at 0.1 , which correlated well with LTA expression with the mouse monoclonal antibody CM2B4. This protocol is generally accepted and widely used $(2,28,30)$. In our 21 samples that were classified as MCV negative due to threshold, only one was weakly positive for TdT and three for PAX5, thus further corroborating the finding of the relationship between TdT and MCV.

MCC was first described in 1972 by Dr. Cyril Toker as "trabecular carcinoma" (31) and was soon recognized as a potential mimicker of malignant lymphoma (32). The resemblance of these two malignancies is related to clinical and microscopic appearances $(32,33)$. The immunohistochemical profile of MCC tumors is somewhat puzzling. The histology of MCC is typical of small round blue cell tumors, an entity that includes a wide variety of the following highly malignant tumors: the Ewing family of tumors, olfactory neuroblastoma, rhabdomyosarcoma, neuroblastoma, lymphoma, desmoplastic small cell tumor, osteosarcoma, small cell lung carcinoma, small cell melanoma, and mesenchymal chondrosarcoma $(34,35)$. Apart from lymphoblastic neoplasms, TdT is expressed in other small round blue cell tumors (36). In particular, another neuroendocrine carcinoma, small cell lung carcinoma, frequently shows high TdT expression (12). Expression of PAX5 in cells other than B lymphocytes has rarely been reported. In small round blue cell tumors, PAX5 is mainly seen in MCC and small cell lung carcinoma $(16,22)$. Expression of PAX5 has also been observed in certain types of poorly differentiated neuroendocrine carcinomas of the gastrointestinal and pancreatobiliary tracts (37). However, the expression of PAX5 in MCC has been considered merely a reflection of cancer-associated dysregulation of protein expression than as an indication of lymphocytic origin of MCC (22). 
The immunophenotypic features of MCC are typical of neuroendocrine carcinomas in other sites. Thus, MCC tumors express low-molecular-weight cytokeratins $(38,39)$. Cytokeratin-20 is the most important and is employed in differential diagnostics, appearing in a dot-like pattern $(40,41)$. Due to its neuroendocrine differentiation, MCC always stains positively for neuron-specific enolase, a general marker of neuroendocrine tumors $(42,43)$. Other frequently expressed neuroendocrine markers include chromogranin-A (44-46), synaptophysin $(46,47)$, and microtubule-associated protein $(46,48)$. With regard to lymphoproliferative markers, CD45 is consistently negative in MCC tumors, along with vimentin, CD5, and CD20 (49,50). Three additional lymphoproliferative markers are nonetheless expressed in a significant proportion of MCCs, namely PAX5, CD99, and TdT (32). However, recent research has revealed that the immunohistochemical features of MCC are to some extent different in MCV-positive and MCV-negative tumors (51). Immunoglobulin expression seems to be restricted to MCV-positive tumors $(21,22)$ and has been postulated to be induced by MCV infection (22).

To conclude, we observed frequent TdT and PAX5 immunoexpression in MCC tumor samples. However, concomitant immunoexpression of these markers was scarce. TdT expression was statistically significantly associated with MCV positivity. The absence of a statistically significant association between tumor parameters and disease progression markers undermines the systemic use of these markers in clinical practice. 


\section{References}

1. Feng H, Shuda M, Chang Y, Moore PS. Clonal integration of a polyomavirus in human Merkel cell carcinoma. Science. 2008;319(5866):1096-1100.

2. Sihto H, Kukko H, Koljonen V, Sankila R, Bohling T, Joensuu H. Clinical factors associated with Merkel cell polyomavirus infection in Merkel cell carcinoma. J Natl Cancer Inst. 2009;101(13):938-945.

3. Iwasaki T, Matsushita M, Kuwamoto S, et al. Usefulness of significant morphologic characteristics in distinguishing between Merkel cell polyomavirus-positive and Merkel cell polyomavirus-negative Merkel cell carcinomas. Hum Pathol. 2013;44(9):1912-1917.

4. Kuwamoto S, Higaki H, Kanai K, et al. Association of Merkel cell polyomavirus infection with morphologic differences in Merkel cell carcinoma. Hum Pathol. 2011.

5. Veija T, Sahi H, Koljonen V, Bohling T, Knuutila S, Mosakhani N. miRNA-34a underexpressed in Merkel cell polyomavirus-negative Merkel cell carcinoma. Virchows Arch. 2015;466(3):289-295.

6. Veija T, Sarhadi VK, Koljonen V, Bohling T, Knuutila S. Hotspot mutations in polyomavirus positive and negative Merkel cell carcinomas. Cancer Genet. 2016;209(1-2):30-35.

7. Motea EA, Berdis AJ. Terminal deoxynucleotidyl transferase: the story of a misguided DNA polymerase. Biochim Biophys Acta. 2010;1804(5):1151-1166.

8. Kung PC, Long JC, McCaffrey RP, Ratliff RL, Harrison TA, Baltimore D. Terminal deoxynucleotidyl transferase in the diagnosis of leukemia and malignant lymphoma. Am J Med. 1978;64(5):788-794.

9. Orazi A, Cattoretti G, John K, Neiman RS. Terminal deoxynucleotidyl transferase staining of malignant lymphomas in paraffin sections. Mod Pathol. 1994;7(5):582-586.

10. Kavalar R, Pohar Marinsek Z, Jereb B, Cagran B, Golouh R. Prognostic value of immunohistochemistry in the Ewing's sarcoma family of tumors. Med Sci Monit. 2009;15(8):CR442-452.

11. Mathewson RC, Kjeldsberg CR, Perkins SL. Detection of terminal deoxynucleotidyl transferase (TdT) in nonhematopoietic small round cell tumors of children. Pediatr Pathol Lab Med. 1997;17(6):835-844.

12. Kolhe R, Reid MD, Lee JR, Cohen C, Ramalingam P. Immunohistochemical expression of PAX5 and TdT by Merkel cell carcinoma and pulmonary small cell carcinoma: a potential diagnostic pitfall but useful discriminatory marker. Int J Clin Exp Pathol. 2013;6(2):142-147.

13. Tzorakoleftheraki SE, Iliadis A, Kostopoulos I, Koletsa T. TdT expression in normal and neoplastic sebaceous cells. Histopathology. 2017.

14. Cobaleda C, Schebesta A, Delogu A, Busslinger M. Pax5: the guardian of B cell identity and function. Nature immunology. 2007;8(5):463-470.

15. Czapiewski P, Majewska H, Kutzner H, Kazakov D, Renkielska A, Biernat W. TTF-1 and PAX5 Are Frequently Expressed in Combined Merkel Cell Carcinoma. Am J Dermatopathol. 2016;38(7):513-516.

16. Dong HY, Liu W, Cohen P, Mahle CE, Zhang W. B-Cell Specific Activation Protein Encoded by the PAX-5 Gene Is Commonly Expressed in Merkel Cell Carcinoma and Small Cell Carcinomas. Am J Surg Pathol. 2005;29(5):687-692.

17. Mhawech-Fauceglia P, Saxena R, Zhang S, et al. Pax-5 immunoexpression in various types of benign and malignant tumours: a high-throughput tissue microarray analysis. Journal of clinical pathology. 2007;60(6):709714.

18. Sur M, Alardati H, Ross C, Alowami S. TdT expression in Merkel cell carcinoma: potential diagnostic pitfall with blastic hematological malignancies and expanded immunohistochemical analysis. Mod Pathol. 2007;20(11):11131120.

19. Buresh CJ, Oliai BR, Miller RT. Reactivity with TdT in Merkel cell carcinoma: a potential diagnostic pitfall. Am J Clin Pathol. 2008;129(6):894-898.

20. Sidiropoulos M, Hanna W, Raphael SJ, Ghorab Z. Expression of TdT in Merkel cell carcinoma and small cell lung carcinoma. Am J Clin Pathol. 2011;135(6):831-838.

21. Zur Hausen A, Rennspiess D, Winnepenninckx V, Speel EJ, Kurz AK. Early B-cell differentiation in Merkel cell carcinomas: clues to cellular ancestry. Cancer Res. 2013;73(16):4982-4987.

22. Murakami I, Takata K, Matsushita M, et al. Immunoglobulin expressions are only associated with MCPyV-positive Merkel cell carcinomas but not with MCPyV-negative ones: comparison of prognosis. Am J Surg Pathol. 2014;38(12):1627-1635. 
23. Pan Z, Chen YY, Wu X, et al. Merkel cell carcinoma of lymph node with unknown primary has a significantly lower association with Merkel cell polyomavirus than its cutaneous counterpart. Mod Pathol. 2014;27(9):1182-1192.

24. Sauer CM, Haugg AM, Chteinberg E, et al. Reviewing the current evidence supporting early B-cells as the cellular origin of Merkel cell carcinoma. Crit Rev Oncol Hematol. 2017;116:99-105.

25. Sahi $\mathrm{H}$, Koljonen $\mathrm{V}$, Kavola $\mathrm{H}$, et al. Bcl-2 expression indicates better prognosis of Merkel cell carcinoma regardless of the presence of Merkel cell polyomavirus. Virchows Arch. 2012;461(5):553-559.

26. Schrama D, Peitsch WK, Zapatka M, et al. Merkel cell polyomavirus status is not associated with clinical course of Merkel cell carcinoma. J Invest Dermatol. 2011;131(8):1631-1638.

27. Sihto H, Kukko H, Koljonen V, Sankila R, Bohling T, Joensuu H. Merkel cell polyomavirus infection, large T antigen, retinoblastoma protein and outcome in Merkel cell carcinoma. Clin Cancer Res. 2011;17(14):4806-4813.

28. Bhatia K, Goedert JJ, Modali R, Preiss L, Ayers LW. Merkel cell carcinoma subgroups by Merkel cell polyomavirus DNA relative abundance and oncogene expression. Int J Cancer. 2010;126(9):2240-2246.

29. Shuda M, Feng $\mathrm{H}$, Kwun HJ, et al. T antigen mutations are a human tumor-specific signature for Merkel cell polyomavirus. Proc Natl Acad Sci U S A. 2008;105(42):16272-16277.

30. Higaki-Mori H, Kuwamoto S, Iwasaki T, et al. Association of Merkel cell polyomavirus infection with clinicopathological differences in Merkel cell carcinoma. Hum Pathol. 2012;43(12):2282-2291.

31. Toker C. Trabecular carcinoma of the skin. Arch Dermatol. 1972;105(1):107-110.

32. Wick MR, Santa Cruz DJ, Gru AA. Non-lymphoid lesions that may mimic cutaneous hematopoietic neoplasms histologically. Semin Diagn Pathol. 2017;34(1):99-107.

33. Sibley RK, Rosai J, Foucar E, Dehner LP, Bosl G. Neuroendocrine (Merkel cell) carcinoma of the skin. A histologic and ultrastructural study of two cases. Am J Surg Pathol. 1980;4(3):211-221.

34. Tarkkanen M, Knuutila S. The diagnostic use of cytogenetic and molecular genetic techniques in the assessment of small round cell tumours. Current Diagnostic Pathology. 2002;8(5):338-348.

35. Pisick E, Skarin AT, Salgia R. Recent advances in the molecular biology, diagnosis and novel therapies for various small blue cell tumors. Anticancer Res. 2003;23(4):3379-3396.

36. Magro G, Longo FR, Angelico G, Spadola S, Amore FF, Salvatorelli L. Immunohistochemistry as potential diagnostic pitfall in the most common solid tumors of children and adolescents. Acta Histochem. 2015;117(4-5):397-414.

37. Ainechi S, Mann SA, Lin J, et al. Paired Box 5 (PAX5) Expression in Poorly Differentiated Neuroendocrine Carcinoma of the Gastrointestinal and Pancreatobiliary Tract: Diagnostic and Potentially Therapeutic Implications. Appl Immunohistochem Mol Morphol. 2016.

38. Moll R, Osborn M, Hartschuh W, Moll I, Mahrle G, Weber K. Variability of expression and arrangement of cytokeratin and neurofilaments in cutaneous neuroendocrine carcinomas (Merkel cell tumors):

immunocytochemical and biochemical analysis of twelve cases. Ultrastruct Pathol. 1986;10(6):473-495.

39. Miettinen M, Lehto VP, Virtanen I, Asko-Seljavaara S, Pitkanen J, Dahl D. Neuroendocrine carcinoma of the skin (Merkel cell carcinoma): ultrastructural and immunohistochemical demonstration of neurofilaments. Ultrastruct Pathol. 1983;4(2-3):219-225.

40. Su LD, Lowe L, Bradford CR, Yahanda Al, Johnson TM, Sondak VK. Immunostaining for cytokeratin 20 improves detection of micrometastatic Merkel cell carcinoma in sentinel lymph nodes. J Am Acad Dermatol. 2002;46(5):661-666.

41. Moll R, Lowe A, Laufer J, Franke WW. Cytokeratin 20 in human carcinomas. A new histodiagnostic marker detected by monoclonal antibodies. Am J Pathol. 1992;140(2):427-447.

42. Leong AS, Phillips GE, Pieterse AS, Milios J. Criteria for the diagnosis of primary endocrine carcinoma of the skin (Merkel cell carcinoma). A histological, immunohistochemical and ultrastructural study of 13 cases. Pathology. 1986;18(4):393-399.

43. Sibley RK, Dahl D. Primary neuroendocrine (Merkel cell?) carcinoma of the skin. II. An immunocytochemical study of 21 cases. Am J Surg Pathol. 1985;9(2):109-116.

44. Wilson BS, Lloyd RV. Detection of chromogranin in neuroendocrine cells with a monoclonal antibody. Am J Pathol. 1984;115(3):458-468.

45. Haneke E, Schulze HJ, Mahrle G. Immunohistochemical and immunoelectron microscopic demonstration of chromogranin A in formalin-fixed tissue of Merkel cell carcinoma. J Am Acad Dermatol. 1993;28(2 Pt 1):222-226.

46. Koljonen V, Haglund C, Tukiainen E, Bohling T. Neuroendocrine differentiation in primary Merkel cell carcinoma-possible prognostic significance. Anticancer Res. 2005;25(2A):853-858. 
47. Buffa R, Rindi G, Sessa F, et al. Synaptophysin immunoreactivity and small clear vesicles in neuroendocrine cells and related tumours. Mol Cell Probes. 1987;1(4):367-381.

48. Liu Y, Mangini J, Saad R, et al. Diagnostic value of microtubule-associated protein-2 in Merkel cell carcinoma. Appl Immunohistochem Mol Morphol. 2003;11(4):326-329.

49. Wong HH, Wang J. Merkel cell carcinoma. Arch Pathol Lab Med. 2010;134(11):1711-1716.

50. Trenkic Bozinovic M, Krasic D, Katic V, et al. Comparative analysis of clinicopathological and immunohistochemical characteristics of Merkel cell carcinoma. J BUON. 2014;19(2):530-534.

51. Jankowski M, Kopinski P, Schwartz R, Czajkowski R. Merkel cell carcinoma: is this a true carcinoma? Exp Dermatol. 2014;23(11):792-794. 
Figure 1 Illustration of staining intensities in PAX-5 and TdT immunohistochemtry.

A) weak PAX-5, B) weak TdT, C) intermediate PAX-5, D) intermediate TdT, E) strong PAX-5

F) strong Tdt. Original magnification 200x
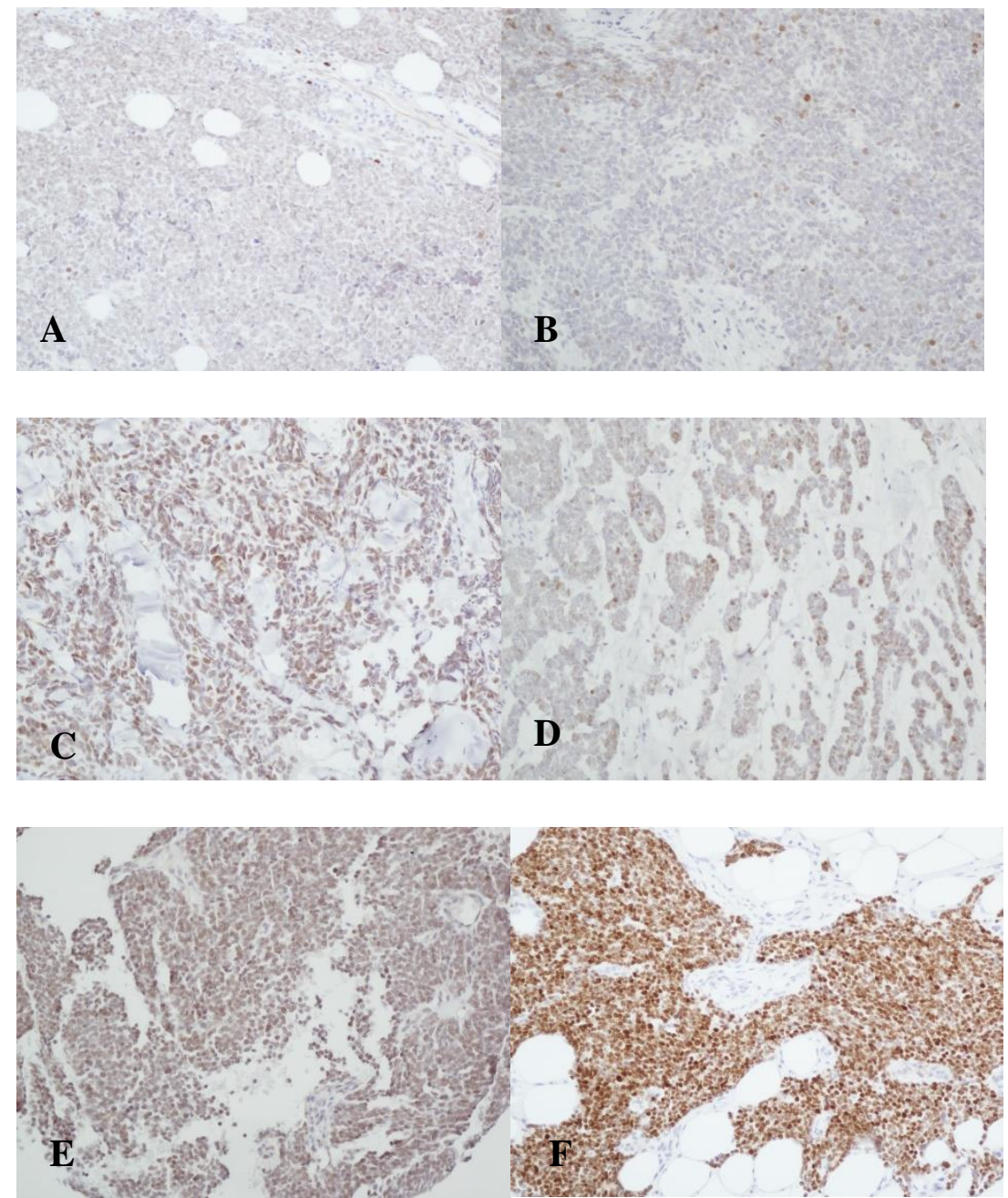

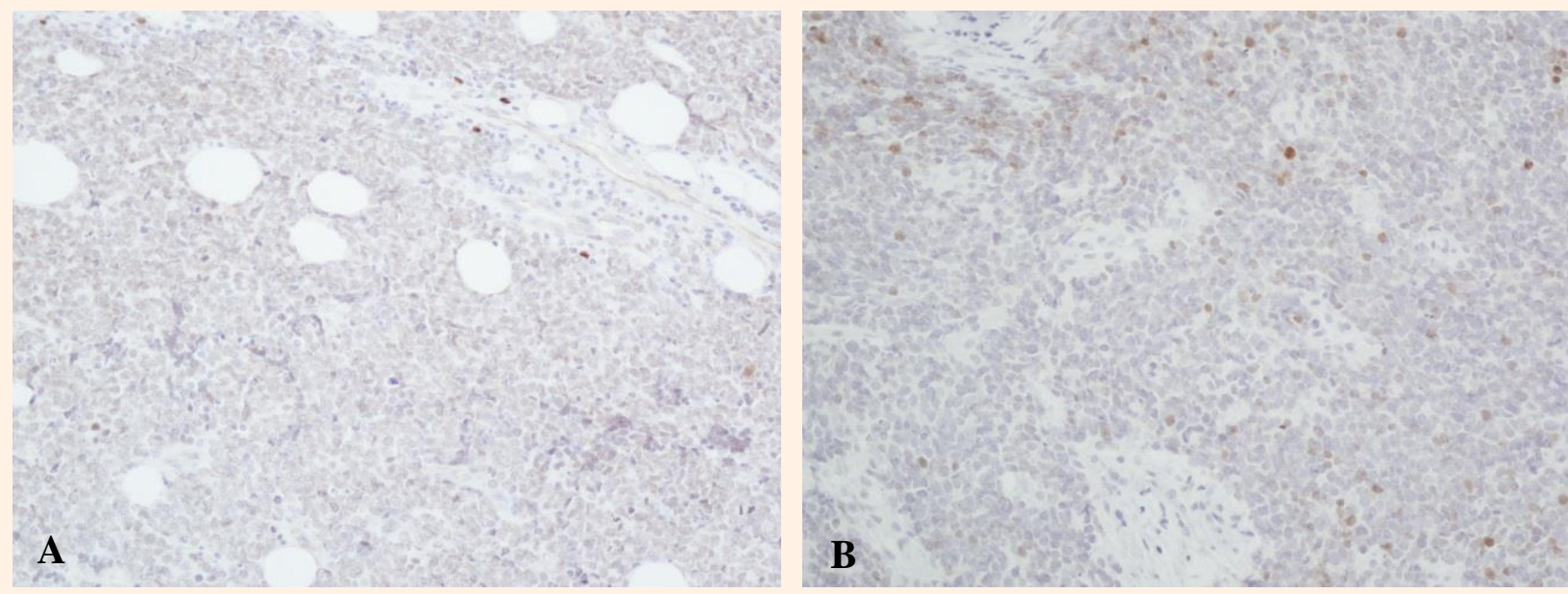

4. - MN

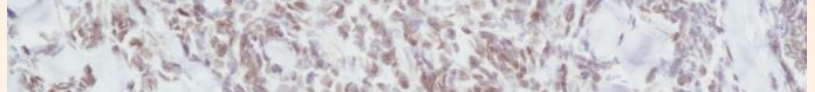

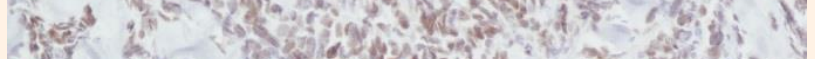

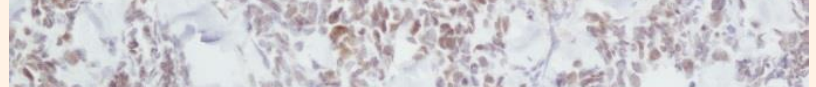

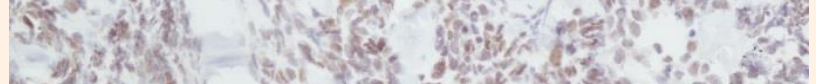
I 5 . 25.

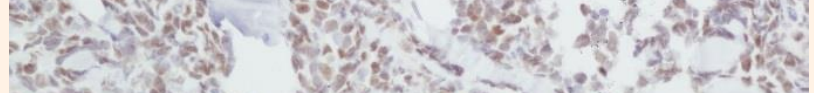

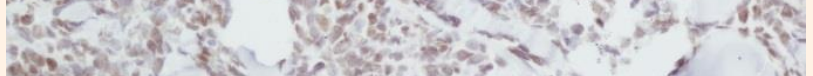

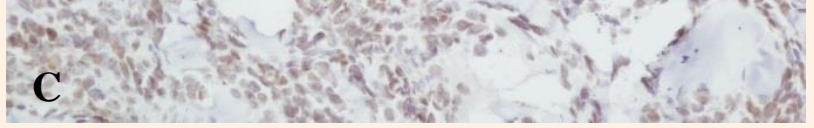
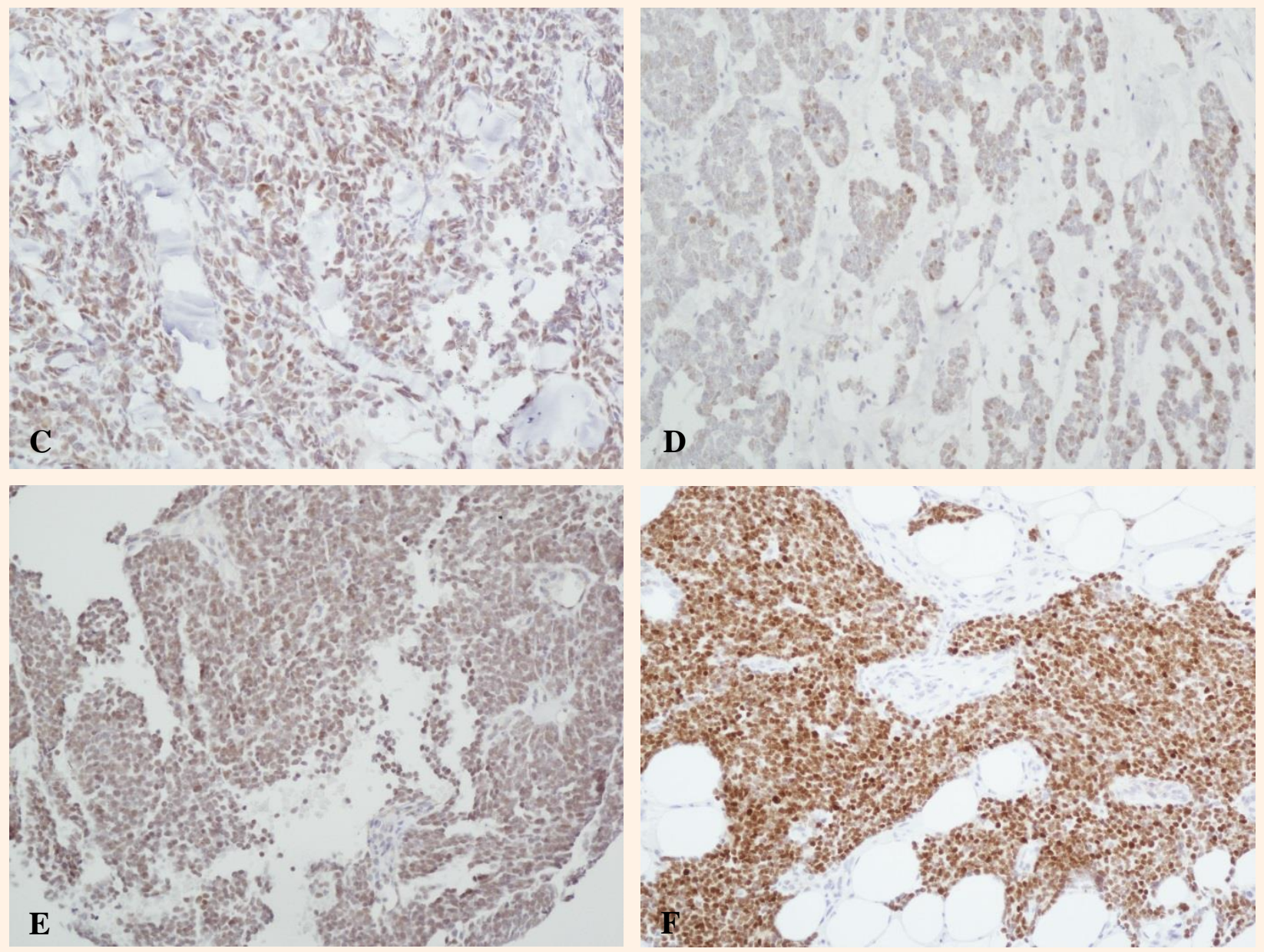
Table 1. A selection of lymphocyte markers studied in Merkel cell carcinoma from 2005-2014.

\begin{tabular}{|c|c|c|c|c|c|c|}
\hline Marker & normally expressed in & Study & Method & Samples & Positive & $\begin{array}{l}\text { MCV+ } \\
\text { MCV- }\end{array}$ \\
\hline \multirow[t]{8}{*}{$T d T$} & pre-B and -T lymphocytes & (Bernd HW et al. 2007) & $\mathrm{IHC}$ & 28 & 10 & NA \\
\hline & & (Sur M et al. 2007) & $\mathrm{IHC}$ & 15 & 8 & NA \\
\hline & & $\begin{array}{c}\text { (Buresh CJ, Oliai BR \& Miller RT } \\
\text { 2008) }\end{array}$ & $\mathrm{IHC}$ & 26 & 19 & NA \\
\hline & & (Bhatia K et al. 2010) & $\mathrm{IHC}$ & 23 & 5 & $\begin{array}{l}5 / 17 \\
0 / 6\end{array}$ \\
\hline & & (Sidiropoulos M et al. 2011) & $\mathrm{IHC}$ & 40 & 28 & NA \\
\hline & & (Murakami I et al. 2014) & $\mathrm{IHC}$ & 30 & 20 & $\begin{array}{c}15 / 20 \\
5 / 10\end{array}$ \\
\hline & & (Kolhe R et al. 2013) & $\mathrm{IHC}$ & 27 & 21 & NA \\
\hline & & (Zur Hausen A et al. 2013) & $\mathrm{IHC}$ & 16 & 21 & $\begin{array}{c}15 / 18 \\
1 / 3\end{array}$ \\
\hline \multirow[t]{5}{*}{ PAX5 } & pre-B lymphocytes & (Dong HY et al. 2005) & $\mathrm{IHC}$ & 31 & 29 & 20 \\
\hline & & (Murakami I et al. 2014) & $\mathrm{IHC}$ & 30 & 30 & $\begin{array}{l}20 / 20 \\
10 / 10\end{array}$ \\
\hline & & (Kolhe R et al. 2013) & $\mathrm{IHC}$ & 27 & 24 & NA \\
\hline & & (Zur Hausen A et al. 2013) & $\mathrm{IHC}$ & 21 & 21 & $\begin{array}{c}18 / 18 \\
3 / 3\end{array}$ \\
\hline & & (Mhawech-Fauceglia P et al. 2007) & $\mathrm{IHC}$ & 34 & 24 & NA \\
\hline Oct2 & $B-$ and $T$ cells, neural cells & (Murakami I et al. 2014) & $\mathrm{IHC}$ & 30 & 27 & $\begin{array}{c}16 / 20 \\
9 / 10\end{array}$ \\
\hline
\end{tabular}




\begin{tabular}{|c|c|c|c|c|c|c|}
\hline \multirow[t]{2}{*}{$\lg G$} & B lymphocytes & (Murakami I et al. 2014) & IHC & 30 & 7 & $\begin{array}{l}7 / 20 \\
0 / 10\end{array}$ \\
\hline & & (Zur Hausen A et al. 2013) & IHC & 21 & 10 & $\begin{array}{c}10 / 18 \\
0 / 3\end{array}$ \\
\hline \multirow[t]{2}{*}{$\lg A$} & B lymphocytes & (Murakami I et al. 2014) & $\mathrm{IHC}$ & 30 & 7 & $\begin{array}{l}7 / 20 \\
0 / 10\end{array}$ \\
\hline & & (Zur Hausen A et al. 2013) & IHC & 21 & 10 & $\begin{array}{c}10 / 18 \\
0 / 3\end{array}$ \\
\hline \multirow[t]{2}{*}{$\lg M$} & B lymphocytes & (Murakami I et al. 2014) & $\mathrm{IHC}$ & 30 & 3 & $\begin{array}{l}3 / 20 \\
0 / 10\end{array}$ \\
\hline & & (Zur Hausen A et al. 2013) & IHC & 21 & 6 & $\begin{array}{l}6 / 18 \\
0 / 3\end{array}$ \\
\hline \multirow[t]{2}{*}{ Igkappa } & B lymphocytes & (Murakami I et al. 2014) & $\begin{array}{c}\text { ISH (mRNA) } \\
\text { IHC }\end{array}$ & $\begin{array}{l}29 \\
28\end{array}$ & $\begin{array}{l}7 \\
7\end{array}$ & $\begin{array}{c}7 / 19 \\
0 / 9-10\end{array}$ \\
\hline & & (Zur Hausen A et al. 2013) & IHC & 21 & 7 & $\begin{array}{l}7 / 18 \\
0 / 3\end{array}$ \\
\hline \multirow[t]{2}{*}{ Iglambda } & B lymphocytes & (Murakami I et al. 2014) & $\begin{array}{c}\text { ISH (mRNA) } \\
\text { IHC }\end{array}$ & $\begin{array}{l}29 \\
29\end{array}$ & $\begin{array}{l}1 \\
0\end{array}$ & $\begin{array}{c}0-1 / 19 \\
0 / 10\end{array}$ \\
\hline & & (Zur Hausen A et al. 2013) & IHC & 21 & 12 & $\begin{array}{c}12 / 18 \\
0 / 3\end{array}$ \\
\hline \multirow[t]{2}{*}{$\lg H-R$} & B lymphocytes & (Murakami I et al. 2014) & PCR & 30 & 20 & $\begin{array}{c}10 / 20^{*} \\
2 / 10\end{array}$ \\
\hline & & (Zur Hausen A et al. 2013) & PCR & 16 & 16 & $\begin{array}{c}14 / 14^{* *} \\
2 / 2\end{array}$ \\
\hline $\lg k$ & & (Zur Hausen A et al. 2013) & PCR & 17 & 17 & $\begin{array}{c}15 / 15^{* * *} \\
2 / 2^{* * *}\end{array}$ \\
\hline CD117 & $\mathrm{HSC}, \mathrm{MPP}, \mathrm{CMP}$ & (Sur M et al. 2007) & IHC & 15 & 8 & NA \\
\hline \multirow[t]{2}{*}{ CD99 } & all leukocytes & (Sur M et al. 2007) & IHC & 15 & 2 & NA \\
\hline & & (Bhatia K et al. 2010) & IHC & 23 & 0 & \\
\hline
\end{tabular}




\begin{tabular}{|c|c|c|c|c|c|c|}
\hline CD10 & $\begin{array}{l}\text { CLP } \\
\text { pre-B lymphocytes }\end{array}$ & (Sur M et al. 2007) & $\mathrm{IHC}$ & 15 & 1 & NA \\
\hline \multirow[t]{2}{*}{ Chromogranin A } & neuroendocrine cells & (Sur M et al. 2007) & $\mathrm{IHC}$ & 15 & 11 & NA \\
\hline & & (Sidiropoulos M et al. 2011) & $\mathrm{IHC}$ & 40 & 29 & NA \\
\hline CD20 & $\begin{array}{l}\text { all B lymphocytes from pro-B cell } \\
\text { phase }\end{array}$ & (Sur M et al. 2007) & $\mathrm{IHC}$ & 15 & 0 & NA \\
\hline CD34 & $\begin{array}{l}\text { B lymphocyte precursors, } \\
\text { myeloid blasts }\end{array}$ & (Sur M et al. 2007) & $\mathrm{IHC}$ & 15 & 0 & NA \\
\hline CD3 & $\begin{array}{l}\text { Tlymphocytes from pro- } \\
\text { thymocytes }\end{array}$ & (Sur M et al. 2007) & $\mathrm{IHC}$ & 15 & 0 & NA \\
\hline
\end{tabular}

*Monoclonal rearrangement detected in $1 \mathrm{MCV}$-positive tumour, others were polyclonal

** Monoclonal rearrangement detected in $1 \mathrm{MCV}$-positive tumour, others were polyclonal

*** Monoclonal rearrangement detected in $3 \mathrm{MCV}$-positive tumours, others were polyclonal 


\section{REFERENCES}

Bernd HW, Krokowski M, Feller AC, Bartsch S \& Thorns C 2007, "Expression of terminal desoxynucleotidyl transferase in Merkel cell carcinomas.", Histopathology, vol. 50, no. 5, pp. 676-678.

Bhatia K, Goedert JJ, Modali R, Preiss L \& Ayers LW 2010, "Merkel cell carcinoma subgroups by Merkel cell polyomavirus DNA relative abundance and oncogene expression.", International Journal of Cancer, vol. 126, no. 9, pp. 2240-2246.

Buresh CJ, Oliai BR \& Miller RT 2008, "Reactivity with TdT in Merkel cell carcinoma: a potential diagnostic pitfall.", American Journal of Clinical Pathology, vol. 129, no. 6 , pp. 894-898.

Dong HY, Liu W, Cohen P, Mahle CE \& Zhang W 2005, "B-cell specific activation protein encoded by the PAX-5 gene is commonly expressed in merkel cell carcinoma and small cell carcinomas.", American Journal of Surgical Pathology, vol. 29, no. 5, pp. 687-692.

Kolhe R, Reid MD, Lee JR, Cohen C \& Ramalingam P 2013, "Immunohistochemical expression of PAX5 and TdT by Merkel cell carcinoma and pulmonary small cell carcinoma: a potential diagnostic pitfall but useful discriminatory marker.", International Journal of Clinical \& Experimental Pathology, vol. 6, no. 2, pp. 142-147.

Mhawech-Fauceglia P, Saxena R, Zhang S, Terracciano L, Sauter G, Chadhuri A, Herrmann FR \& Penetrante R 2007, "Pax-5 immunoexpression in various types of benign and malignant tumours: a high-throughput tissue microarray analysis.", Journal of clinical pathology, vol. 60, no. 6, pp. 709-714.

Murakami I, Takata K, Matsushita M, Nonaka D, Iwasaki T, Kuwamoto S, Kato M, Mohri T, Nagata K, Kitamura Y, Yoshino T \& Hayashi K 2014, "Immunoglobulin expressions are only associated with MCPyV-positive Merkel cell carcinomas but not with MCPyV-negative ones: comparison of prognosis.", American Journal of Surgical Pathology, vol. 38, no. 12, pp. 1627-1635.

Sidiropoulos M, Hanna W, Raphael SJ \& Ghorab Z 2011, "Expression of TdT in Merkel cell carcinoma and small cell lung carcinoma.", American Journal of Clinical Pathology, vol. 135, no. 6, pp. 831-838.

Sur M, AlArdati H, Ross C \& Alowami S 2007, "TdT expression in Merkel cell carcinoma: potential diagnostic pitfall with blastic hematological malignancies and expanded immunohistochemical analysis.", Modern Pathology, vol. 20, no. 11, pp. 1113-1120.

Zur Hausen A, Rennspiess D, Winnepenninckx V, Speel EJ \& Kurz AK 2013, "Early B-cell differentiation in Merkel cell carcinomas: clues to cellular ancestry.", Cancer research, vol. 73 , no. 16 , pp. 4982-4987. 
Table 2. Clinicopathological features of patients

\begin{tabular}{|l|l|}
\hline N & $117(\%)$ \\
\hline Mex & $32(27)$ \\
Female & $85(73)$ \\
\hline Age & range $27-100$ \\
$\leq \geq 50$ years & $3(2.5)$ \\
$51-69$ years & $19(17)$ \\
$70-84$ & $59(50)$ \\
$85-100$ & $36(22)$ \\
\hline Imunocompromised state & \\
Hematologic malignancy & 2 \\
NHL & 5 \\
CLL & $(6)$ \\
Organ transplant & $2(1.7)$ \\
Kidney & \\
\hline Tumour location & $65(56)$ \\
Head and neck & $5(4)$ \\
Torso anterior & $10(8)$ \\
Torso posterior & $22(18)$ \\
Upper extremities & $15(12)$ \\
Lower extremities & \\
\hline Tumour laterality & $58(50)$ \\
Left & $52(45)$ \\
Right & $1(0.9)$ \\
Midline & $6(5.1)$ \\
$\quad$ Not available & $41(35)$ \\
\hline Disease progression & $29(26)$ \\
$\quad$ metastasis & $84(74)$ \\
$\quad$ Negative & $4(3,4)$ \\
$\quad$ Positive & \\
$\quad$ Not available & \\
\hline
\end{tabular}

MCV Merkel cell polyoma virus 
Table 3. Overview of the immunohistochemical results of TdT and PAX5 results stratified by expression intensity and Merkel cell polyoma virus (MCV) status

\begin{tabular}{|c|c|c|c|c|}
\hline & TdT & MCV positive, $n$ & Pax-5 & MCV positive, $n$ \\
\hline Negative, $n$ & 80 & 50 & 91 & 65 \\
\hline Weak positive, $n$ & 23 & \multirow[t]{2}{*}{34} & 20 & \multirow[t]{2}{*}{19} \\
\hline Positive, $n$ & 14 & & 6 & \\
\hline \multirow{4}{*}{$\begin{array}{l}\text { Simultaneous TdT } \\
\text { and Pax-5 }\end{array}$} & & & & \\
\hline & \multirow{3}{*}{13} & \multirow{3}{*}{12} & $\begin{array}{l}\text { Strong TdT and } \\
\text { strong Pax }-5\end{array}$ & 4 \\
\hline & & & $\begin{array}{l}\text { Weak TdT and } \\
\text { weak Pax-5 }\end{array}$ & 8 \\
\hline & & & $\begin{array}{l}\text { Strong TdT and } \\
\text { weak Pax-5 }\end{array}$ & 1 \\
\hline $\begin{array}{l}\text { Negative for TdT } \\
\text { and Pax-5 }\end{array}$ & 66 & 43 & & \\
\hline
\end{tabular}

